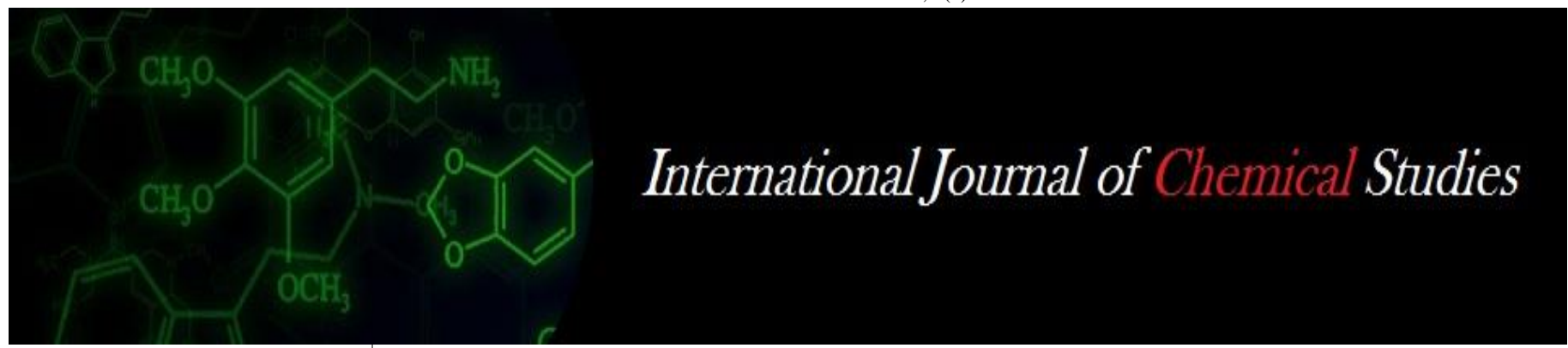

P-ISSN: 2349-8528

E-ISSN: 2321-4902

www.chemijournal.com

IJCS 2020; 8(3): 263-265

(C) 2020 IJCS

Received: 19-03-2020

Accepted: 21-04-2020

\section{BDS Nathawat}

Agricultural Research Station,

Bikaner, Rajasthan, India

\section{OP Sharma}

College of Agriculture, Bikaner,

Rajasthan, India

\section{AL Yadav}

S. K. Rajasthan Agriculture

University, Bikaner, Rajasthan,

India
Corresponding Author: BDS Nathawat

Agricultural Research Station,

Bikaner, Rajasthan, India

\section{Studies on the incidence of wilt disease in major chickpea growing areas}

\author{
BDS Nathawat, OP Sharma and AL Yadav
}

DOI: $\underline{\text { https://doi.org/10.22271/chemi.2020.v8.i3d.9238 }}$

\section{Abstract}

Wilt disease of chickpea (Cicer arirtinum) induced by Fusarium oxysporum f. sp. ciceri (Padwick) was found to be prevalent in all districts of Rajasthan surveyed. The disease varied from mild to severe from. In Sikar, it was maximum (30.80 and 31.90 per cent) fallowed by Hanumangarh, Sriganganagar and Jaipur in 2014-15 and 2015-16. Least wilt disease incidence was observed 19.05 and 19.75 per cent in Tonk district.

Keywords: Wilt, Fusarium oxysporum f. sp. ciceri, chickpea, Rajasthan

\section{Introduction}

Chickpea (Cicer arietinum L) commonly known as "chana" in Hindi belongs to family Leguminosae and is believed to have originated from south west Asia (Singh, 1993).It is an important pulse crop and grown in temperate as well as subtropical regions of the world. It accounts for 70 per cent to the cultivated Rabi pulses in India. The major chickpea growing states in India are Madhya Pradesh, Rajasthan, Andhra Pradesh, Bihar, Uttar Pradesh, Maharashtra, Haryana and Karnataka. The total area under chickpea cultivation in India is about 9.93 million hectare with annual production of 9.53 million tonnes. The average productivity of chickpea is $960 \mathrm{~kg} / \mathrm{ha}$ (Annonymous, 2015) ${ }^{[2]}$.

In Rajasthan, the major chickpea growing districts are Churu, Jhunjhunu, Sikar, Jaipur Shriganganager, Tonk, Alwar and Hanumangarh. The total area and production of chickpea in Rajasthan is 1.06 million hectares and 0.998 million tonnes, respectively, having productivity of $937 \mathrm{~kg} / \mathrm{ha}$ (Annonymous, 2015) ${ }^{[2]}$.

More than 50 pathogens have been reported to infect chickpea crop but only few cause economically important diseases. Among them, Fusarium wilt (Fusarium oxysporum f. sp. ciceri (Pad Wick) Snyd. \& Hans), black root rot (Fusarium solani (Mart.) Sacc.), wet root rot (Rhizoctonia solani) and dry root $(R$. bataticola) and collar rot (Sclerotium rolfsii) are of considerable importance (Nene et. al., 1981) ${ }^{[10]}$. Fusarium wilt is one of the important limiting factors of chickpea production in India. Chickpea wilt caused by Fusarium oxysporum $\mathrm{f}$.sp. ciceri was first reported from India by Butler (1918) ${ }^{[4]}$. Black root rot / Wilt caused by Fusarium solani (Mart.) Sacc. causes severe yield loss i.e. 60-70 per cent under favourable conditions (Tewari and Mukhopadhyay, 2003) ${ }^{[5]}$. The diseases caused by soil borne fungal pathogens viz., Rhizoctonia solani (root-rot), Fusarium oxysporum f. sp. ciceri (wilt) and Sclerotium rolfsii have been considered as most devastating for the production of chickpea (Singh et al., 1986; Khan et al., 2002) ${ }^{[13,8]}$. The disease is wide spread in the chickpea growing areas of the world and reported from at least 33 countries (Nene et. al., 1996) ${ }^{[11]}$. In India, it has been reported from all the chickpea growing states and causes an annual loss of 10\% (Singh and Dahiya, 1973) ${ }^{[14]}$. The disease can affect the crop at any stage of growth. Early wilting causes $77-94 \%$ losses while late wilting causes 24- 65\% loss (Haware and Nene, 1980) ${ }^{[6]}$.

Among the fungal diseases, chickpea wilt caused by Fusarium oxysporum f. sp. ciceri is widespread in several countries of the world like India, Iran, Pakistan, Nepal, Burma, Spain, Mexico, Peru, Syria and USA (Nene et. al., 1989; Jalali and Chand, 1992) ${ }^{[12,7]}$. It is one of the important limiting factors of chickpea production in India. The disease causes substantial yield losses which may reach even 100 per cent under favourable weather conditions (Nene, 1980 and Jalali and Chand, 1992) ${ }^{[9,7]}$. 


\section{Material and Method}

Survey was undertaken to major chickpea growing districts of Rajasthan to know the prevalence of wilt disease. Observations on wilt disease incidence were recorded. The selection of village and fields was done randomly. To assess the disease incidence, five fields were observed in each village and average incidence of the disease in each village was calculated. In each field, marked randomly, diseased and healthy plants were counted in one square meter area, in a field, four such spots were randomly selected and average incidence of field was calculated. The per cent disease incidence was calculated as per formula given below

Percentage disease incidence $=\frac{\text { Number of infected plants }}{\text { Total number of plants observed }} \times 100$

Survey was carried out in Jaipur, Sikar, Alwar, Tonk, Jodhpur, Sriganganagar and Hanumangarh districts of Rajasthan.

\section{Results and Discussion \\ Survey}

Survey for the occurrence of chickpea wilt was undertaken in Jaipur, Sikar, Alwar, Tonk, Jodhpur, Sriganganagar and Hanumangarh districts of Rajasthan during 2014-15 and 2015-16. Extensive survey revealed that the disease was present in varying intensities in all the districts surveyed.

\section{Distribution and incidence of the disease}

It is apparent from the data depicted in table-4.1 that the wilt disease (Fusarium oxysporum f. sp. ciceri) incidence in different districts varied from 19.05 to 30.80 per cent in the year 2014-15.In Sikar,it was maximum (30.80) fallowed by Hanumangarh, Sriganganagar and Jaipur having incidence to the true of $28.55,28.20$ and 26.10 per cent respectively in 2014-15.Least wilt disease incidence was observed 19.05 percent in Tonk district.in the crop year 2015-16 the wilt disease incidence in different districts ranged between 20.06 to 33.00 per cent. In Sikar, it was maximum (33.00 per cent) fallowed by Hanumangarh, Sriganganagar and Jaipur having incidence to the $29.95,28.90$ and 26.27 per cent respectively in 2015-16. Least wilt disease incidence was observed 20.06 per cent in Alwar district (Table-1 and Fig.1). If we compare mean wilt incidence of both the years it ranged between 19.75-31.90 per cent. It was maximum 31.90 per cent in Sikar followed by Hanumangarh, Sriganganagar and Jaipur having disease incidence to the tune of $25.25,28.55$ and 26.18 per cent. the above result are accordance with the scientist . Gangwar et al., (2014) ${ }^{[5]}$ who observed the highest incidence $(45.88 \%)$ in Mohangarh area of district Jaisalmer and minimum $(27.43 \%)$ in Ahore area of district Jalore. Division wise highest disease incidence $(40.58 \%)$ was observed in Jaipur division followed by Jodhpur division (37.48\%), Ajmer division (37.46\%) and Bikaner division (34.31\%).Several successful end had been made in survey of Fusarium wilt (Thaware et al.2015 and Andrabi et al. 2008) ${ }^{[16,1]}$ who found that maximum in the district of Parbhani $(15.73 \%)$ followed by Nanded $(15.63 \%)$ and Hingoli $(14.93 \%)$ districts in the years 2013-2014 and 2014-2015.

Table 1: Per cent disease incidence of wilt of chickpea induced by $F$. oxysporum f.sp. ciceri in different districts of Rajasthan

\begin{tabular}{|c|c|c|c|c|c|c|c|c|}
\hline \multirow{2}{*}{\multicolumn{2}{|c|}{$\begin{array}{c}\text { District / Block } \\
\text { Jaipur }\end{array}$}} & \multicolumn{3}{|c|}{ Wilt disease incidence (2014-15) } & \multicolumn{3}{|c|}{ Wilt disease incidence (2015-16) } & \multirow[t]{2}{*}{ Mean of total wilt* } \\
\hline & & Seedling stage & Maturity stage & Total & Seedling stage & Maturity stage & Total & \\
\hline 1 & Bassi & 14.60 & 10.30 & 24.90 & 14.50 & 10.20 & 24.70 & 24.80 \\
\hline 2 & Chomu & 13.80 & 11.20 & 25.00 & 14.30 & 11.20 & 25.50 & 25.25 \\
\hline 3 & Dudu & 14.30 & 12.30 & 26.60 & 14.60 & 12.30 & 26.90 & 26.75 \\
\hline \multirow[t]{2}{*}{4} & Phagi & 15.30 & 12.60 & 27.90 & 15.20 & 12.80 & 28.00 & 27.95 \\
\hline & Average & 14.50 & 11.60 & 26.10 & 14.65 & 11.62 & 26.27 & 26.18 \\
\hline \multicolumn{9}{|c|}{ Sikar } \\
\hline 1 & Reengus & 16.00 & 11.00 & 27.00 & 19.60 & 11.00 & 30.60 & 28.80 \\
\hline \multirow[t]{2}{*}{2} & Khandela & 24.60 & 10.00 & 34.60 & 25.60 & 9.80 & 35.40 & 35.00 \\
\hline & Average & 20.30 & 10.50 & 30.80 & 22.60 & 10.40 & 33.00 & 31.90 \\
\hline \multicolumn{9}{|c|}{ Tonk } \\
\hline 1 & Diggi & 10.80 & 8.60 & 19.40 & 11.30 & 9.20 & 20.50 & 19.95 \\
\hline \multirow[t]{2}{*}{2} & Uniyara & 10.90 & 7.80 & 18.70 & 10.80 & 9.60 & 20.40 & 19.55 \\
\hline & Average & 10.80 & 8.20 & 19.05 & 11.05 & 9.40 & 20.45 & 19.75 \\
\hline \multicolumn{9}{|c|}{ Alwar } \\
\hline 1 & Thanagaji & 11.30 & 8.60 & 19.90 & 11.10 & 8.40 & 19.80 & 19.85 \\
\hline 2 & Nagaon & 12.30 & 7.80 & \begin{tabular}{|l|}
10.10 \\
\end{tabular} & 11.80 & 8.20 & 20.00 & 20.05 \\
\hline \multirow[t]{2}{*}{3} & Rajgarh & 10.30 & 9.11 & 19.41 & 10.80 & 9.60 & 20.40 & 19.90 \\
\hline & Average & 11.30 & 8.50 & 19.80 & 11.33 & 8.73 & 20.06 & 19.93 \\
\hline \multicolumn{9}{|c|}{ Jodhpur } \\
\hline 1 & Borunda & 11.30 & 10.11 & 21.41 & 12.30 & 11.10 & 23.40 & 22.40 \\
\hline \multirow[t]{2}{*}{2} & Osian & 12.30 & 11.30 & 23.60 & 13.30 & 11.10 & 24.40 & 24.00 \\
\hline & Average & 11.80 & 10.70 & 22.50 & 12.80 & 11.10 & 23.90 & 23.20 \\
\hline \multicolumn{9}{|c|}{ Sriganganagar } \\
\hline 1 & Suratgarh & 14.60 & 12.20 & 26.80 & 15.60 & 13.20 & 28.80 & 27.80 \\
\hline 2 & Vijay Nagar & 15.80 & 13.80 & 29.60 & 16.20 & 12.80 & 29.00 & 29.30 \\
\hline \multirow[t]{2}{*}{3} & Jetsar & 15.20 & 13.00 & 28.20 & 15.90 & 13.00 & 28.90 & 28.55 \\
\hline & Average & 15.20 & 13.00 & 28.20 & 15.90 & 13.00 & 28.90 & 28.55 \\
\hline \multicolumn{9}{|c|}{ Hanumangarh } \\
\hline 1 & Nohar & 16.60 & 11.80 & 28.40 & 17.60 & 12.20 & 29.80 & 29.10 \\
\hline \multirow[t]{2}{*}{2} & Rawatsar & 15.90 & 12.80 & 28.70 & 16.90 & 13.20 & 30.10 & 29.40 \\
\hline & Average & 16.25 & 12.30 & 28.55 & 17.25 & 12.70 & 29.95 & 29.25 \\
\hline
\end{tabular}

*Mean of total wilt incidence of two year (2014-15 and 2015-16) 


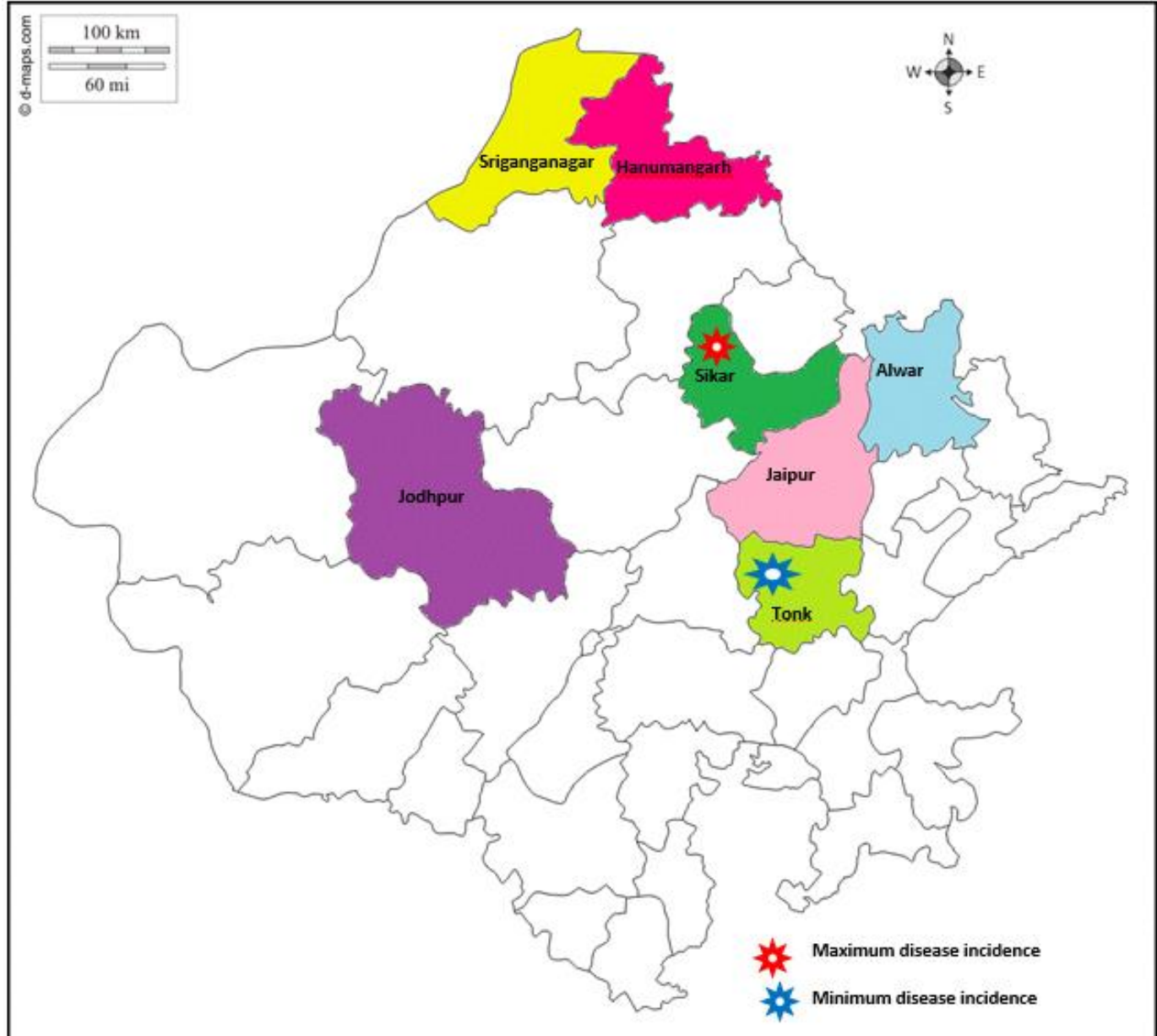

Fig 1: Per cent disease incidence of wilt of chickpea induced by $F$. oxysporum f.sp. ciceri in different districts of Rajasthan

\section{References}

1. Andrabi M, Vaid A, Razdan VK. Occurrences of chickpea wilt complex and its causal agents in Jammu. J Pl. Protec. Res. 2008; 7(1):1-8

2. Annonymous. dacnet.nic.in. (Department of Agriculture and Cooperation) Developed by Agricultural Informatics Division, National Informatics Centre, Department of Information Technology, Ministry of Information and Communication Technology, 2015.

3. Anonymous. Vital Agricultural Statistics, Directorate of Agriculture, Rajasthan, Jaipur, 2015.

4. Butler EJ. Fungi and diseases of plants. Bishen Singh Mahendra Pal Singh, New Connaugh Place., Dehradun Periodical Experts. 42-D, Vivek Vihar, Delhi, 1918; 32:547. (reprinted, 1973).

5. Gangwar RK, Shalini, Singh TP, Verma LN, Gupta NK, Agarwal NK. Studies on the status of chickpea wilt in Rajasthan. Agriways. 2014; 1(1):38-41.

6. Haware MP, Nene YL. Influence of wilt at different growth stages and yield loss in chickpea. Tropic. Grain Legume Bull. 1980; 19:38-40.

7. Jalali BL, Chand H. Chickpea wilt. Plant Diseases of International Importance. 1992; 1:429-444.

8. Khan IA, Alam SS, Haq A, Jabbar A. Selection for resistant to wilt in relaton with phenols in chickpea. Int. Chickpea Pigeonpea Newslett. 2002; 9:19-20.

9. Nene YL. Diseases of chickpea. in Proceedings of International Workshop on Chickpea Improvement, 28 February-2 March 1979, ICRISAT, India. Patancheru, AP 502 324, India: Int. Crops Res. Inst. for the SemiArid Tropics. 1980, 171-178
10. Nene YL, Haware MP, Reddy MV. Chickpea diseases: Resistance-screening techniques. Information Bulletin No.10, Patancheru, A.P., India; International Crops Research Institutes for Semi Arid Tropics, 1981.

11. Nene YL, Sheila VK, Sharma SB. A World List of Chickpea and Pigeonpea Pathogens, ICRISAT, Patancheru, 5th edn, 1996, 27.

12. Nene YL, Sheila VK, Sharma SB. A world list of chickpea (Cicer arietinum L.) and pigeonpea (Cajanus cajan L.) Millsp. pathogens. ICRISAT legumes pathology progress report Patancheru, India, 1989, 7.

13. Singh F, Singh N, Gupta PK. Fusarium wilt of chickpea. Current status of the study and measures to reduce crop losses, 1986, 133-148.

14. Singh KB, Dahiya BS. Breeding for wilt resistance in chickpea. Pages 13-14. In: Symposium on Wilt Problem and Breeding for Wilt Resistance in Bengal Gram. Indian Agriculture Research Institute, New Delhi, India, 1973.

15. Tewari AK, Mukhopadhyay AN. Management of chickpea root rot and collar rot by integration of biological and chemical seed treatment. Ind. Phytopathol. 2003; 56(1):39-42.

16. Thaware DS, Kohire OD, Gholve1 VM. Survey of chickpea wilt (Fusarium oxysporum f.sp. ciceri) disease in Marathwada region of Maharashtra state. Adv. Res. J of Improv. 2015; 6:134-138. 